\title{
Ohmic Heating as an Alternative to Conventional Heating for Shelf Life Enhancement of Fruit Juices
}

\author{
Sourav Misra and Sitesh Kumar* \\ Agricultural and Food Engineering Department, Indian Institute of Technology Kharagpur, \\ West Bengal -721302, India \\ *Corresponding author
}

\section{A B S T R A C T}

\section{Keywords}

Ohmic heating, Fruit juice, Shelf life, Spoilage

Article Info

Accepted:

05 February 2020

Available Online:

10 March 2020
India, being a leading producer of fruits and vegetables, novel thermal technologies should gain popularity from the point of enhancing the shelf life with minimal degradation of nutritional and organoleptic parameters of food materials. Ohmic heating, also known as electrical resistance heating, Joule heating, and direct electrical resistance heating in which the conversion of electrical energy into volumetric heating takes place without any environmental hazards. Ohmic heating is a recent advancement for different applications in food processing sectors, especially for inactivation of enzymes in fruit juices. The present review work briefly emphasizes on factors to be considered during ohmic heating for fruit juices as well as optimization of the factors to minimize the undesirable physicochemical changes occurring during the treatment period. Different configurations of ohmic heating set up have been demonstrated in various research institutes of India. From the point of commercialization, ohmic heating can be acceptable for treating the fruits and vegetables for preventing the spoilage due to enzymatic browning. Thus the shelf life of fruits and vegetables can be extended to some more weeks so that it will meet the demand of consumers to get higher qualitative foods.

\section{Introduction}

Development of new products and process technologies is necessary from the point of increasing demand of consumers for high quality foods. Heating methodologies have advanced remarkably with the new era of novel technologies such as ohmic heating, dielectric heating (including microwave heating and radio frequency heating) etc. These processing methods are effective because of volumetric heating of foods. Ohmic heating, also known as Joule heating, electrical resistance heating, and direct electrical resistance heating in which electric current is passed through the object that acts 
as an electric resistance. Then electrical energy generates volumetric heating in the food material. Uniform distribution of temperature as well as uniform heating are the salient features of ohmic heating.

India is the second leading country in the world producing 90.2 million metric tons of fruits and 169.1 million metric tons of vegetables during 2015-16 (NHB 2015-16). The production of pulp and fruit juice production increased from 150.8 to 158 thousand metric tons during 2015-18 (Statista 2018). Enzymatic browning leads to spoilage in quality parameters in fruits and vegetables is a common phenomenon due to mechanical damage and many unit operations including cutting, slicing, dicing, pulping etc. Heating treatment is often applied for deactivation of the appropriate enzymes (Yemenicioglu and Cemeroglu, 1998). The conventional heating methods apply high temperature which shows greater degradation of sensory and nutritional qualities of food material. In ohmic heating, food components are placed in electric circuit, behaving as an element, through which an alternating current (AC) passed, resulting in volumetric heating of food without causing any transmission losses (Sarang et al., 2008; Morgan, 2009). Shortening the treatment period and internal heat generation with minimal degradation of heat sensitive compounds are the attractive features of ohmic heating without causing any environmental hazards (Machado et al., 2010). The present review paper summarizes the parameters influencing the design of ohmic heating chamber as well as the heating process and the physico-chemical changes of fruit juices exposed to ohmic heating.

Factors to be considered during ohmic heating of fruit juices

Numerous variables are affecting ohmic heating of food material such as electrical conductivity, strength of electric field, ionic concentration, particle orientation, and electrodes.

\section{Electrical conductivity}

Electric conductivity of food samples is the most deciding parameter from the point of designing of an efficient ohmic heater (Sarang et al., 2008). The rate of electrical resistance heating varies as second power of the electrical conductivity and electrical field strength (Sastry et al., 1992). Castro et al., (2003) did research work on fresh strawberry and selected the range of temperature of 25$100^{\circ} \mathrm{C}$ to measure electrical conductivity which showed increasing trend in electrical conductivity but the reverse conditions identified for strawberry pulp. Sarang et al., (2008) quantified electrical conductivity of peach and pear over a wide range of temperature $25-140^{\circ} \mathrm{C}$. Singh et al., (2008) measured the electrical conductivity for apple juice over a temperature range of $25-70^{\circ} \mathrm{C}$ during the exposure to ohmic heating. Qihua et al., (1993) investigated that electrical conductivity showed nonlinear relationship with temperature in orange juice. Icier et al., (2004) investigated that there was increasing the electrical conductivity values of sourcherry and apple juice concentrates with temperature irrespective of all voltage gradients. Darvishi et al., (2013) observed the decreasing trend of electrical conductivities with temperature rise.

\section{Electrical field strength}

Increasing in the ohmic heating rate occurs due to increment in the electrical field intensity and electrical conductivity. Vikram et al., (2005) used electrical field strength of $42 \mathrm{~V} / \mathrm{cm}$ and analyzed the deterioration kinetics of ascorbic acid in orange juice. Similar work was done by Lima (1996), in which orange juice was treated at temperature 
of $90^{\circ} \mathrm{C}$ for the exposure time of $30 \mathrm{~min}$ with the application of electrical field strength of $18.2 \mathrm{~V} / \mathrm{cm}$. Castro et al., (2004) conducted experiment on inactivation kinetics of enzymes exposing to joule heating of apple juice by taking combinations of electrical field strength and frequency range $20 \mathrm{~V} \mathrm{~cm}^{-1}$ and $50 \mathrm{~Hz}$ respectively. Icier et al., (2005) had taken the combinations of electrical field strength and frequency $(60 \mathrm{~V} / \mathrm{cm}$ and $50 \mathrm{~Hz}$ to $1 \mathrm{MHz}$ ) for evaluating the rate of ohmic heating of peaches. Similarly, inactivation of polyphenoloxidase enzyme, physical properties of apple juice was studied by Moreno et al., (2013) at $13 \mathrm{~V} / \mathrm{cm}$ of voltage gradient.

\section{Ionic concentration}

The rate of ohmic heating was greatly affected by increasing rate of concentration of ions. Icier et al., (2005) observed that the rate of joule heating was higher in peach puree due to higher acidic in nature.

\section{Particle orientation}

Particle orientation plays a major role in the ohmic heating system. Zareifard et al., (2003) investigated that higher rate of joule heating occurred in the liquid phase as compared to the solid phase for the parallel condition, while the opposite conditions were revealed in the series condition.

\section{Selection of electrodes}

Losses due to heat are caused by the electrodes during ohmic heating (De Alwis et al., 1990). There is a variation while measuring the temperature by using thermocouple positioned at the center and positioned closely to the electrodes (Marcotte et al., (1998). Zell et al., (2011) used various metals as electrode material such as titanium, Stainless steel, aluminum and platinized titanium. Tzedakis et al., (1999) concluded that platinized titanium showed insignificant electrocatalytic effects upon the food materials and recommended as the most suitable electrode material for giving a satisfactory heating rate.

\section{Ohmic heating setup for treatment of fruit juices}

Heating cell, data logger system, AC power source, electrodes, voltage control unit and thermocouples are the major parts of ohmic heating system unit. Many researchers had tested several configurations for designing the treatment chamber. Jakob et al., (2010) analyzed inactivation kinetics of food enzymes in fresh apple juice during joule heating. The research works were conducted in a cylindrical glass reactor of inner diameter and length of $2.4 \mathrm{~cm}$ and $6.0 \mathrm{~cm}$ respectively attached with stainless steel electrodes. The temperature was measured by using resistance thermometer, made up of platinum. Moreno et al., (2013) exposed apple juice to ohmic heating by immersing the sample in concentric cylindrical tanks $(3.7 \mathrm{~cm}$ and $19 \mathrm{~cm}$ in diameter) made of stainless steel positioned with two electrodes which was connected to a generator. The alternating current with frequency and voltage of $60 \mathrm{~Hz}$ and $100 \mathrm{~V}$ was supplied to the control panel which had the capacity of generating a voltage gradient of $13 \mathrm{~V} / \mathrm{cm}$. To detect the temperature, voltage and current continuously, OM-420 data logger was connected. Castro et al., (2004) conducted experiment by taking apple juice in the ohmic treatment chamber which consisted of a cylindrical glass tube of length of $30 \mathrm{~cm}$ and $2.3 \mathrm{~cm}$ inside dia and temperature was measured by using three nos. of thermocouple placed centrally. Two electrodes were made up of titanium. The control system was operated with an alternating current with the combinations of electrical field strength and frequency $\left(20 \mathrm{~V} \mathrm{~cm}^{-1}\right.$ and $\left.50 \mathrm{~Hz}\right)$. 
Table.1 Effect of ohmic heating on viability of microorganisms in different food materials

\begin{tabular}{|c|c|c|c|c|}
\hline Food & Microorganism & Processing parameters & Findings & References \\
\hline Goat milk & $\begin{array}{c}\text { Escherichia coli ATCC } \\
25922\end{array}$ & $\begin{array}{c}\text { Electrical field }-20-54 \mathrm{~V} / \mathrm{cm} \\
\text { Electrode gap- } 2 \mathrm{~cm} \\
\text { Frequency- } 50 \mathrm{~Hz}\end{array}$ & $\begin{array}{l}\text { D-value for OH sample less than } \\
\text { conventional heating. }\end{array}$ & Pereira et al., (2007) \\
\hline \multirow[t]{2}{*}{ Milk } & $\begin{array}{c}\text { Streptococcus } \\
\text { thermophilus } 2646\end{array}$ & \multirow[t]{2}{*}{$\begin{array}{c}\text { Voltage- } 70-12 \mathrm{~V} \\
\text { Current- } 7.3-2 \mathrm{~A} \\
\text { Electrode gap- } 3 \mathrm{~cm}\end{array}$} & $\begin{array}{l}\mathrm{D}_{70}=6.59 \\
\mathrm{D}_{75}=3.09 \\
\mathrm{D}_{80}=0.16\end{array}$ & \multirow[t]{2}{*}{ Sun et al., (2008) } \\
\hline & Viable aerobes & & $\begin{array}{l}\mathrm{D}_{57}=8.64 \\
\mathrm{D}_{60}=6.18 \\
\mathrm{D}_{72}=0.38\end{array}$ & \\
\hline Buffalo milk & $\begin{array}{l}\text { Total visible colonies, } \\
\text { yeasts and molds, } \\
\text { coliforms, E.coli, } \\
\quad \text { Salmonella }\end{array}$ & $\begin{array}{l}\text { Voltage varied to match the thermal } \\
\text { conditions of conventional heating. } \\
\text { Temperature- } 72^{\circ} \mathrm{C} \\
\text { Electrode gap- } 2.9 \mathrm{~cm}\end{array}$ & $\begin{array}{l}\text { Higher reductions of total visible } \\
\text { colonies, yeasts and molds, E.coli } \\
\text { and coliforms }(6.04,6.52, \\
5.78 \text {, and } 6.26 \mathrm{log} \\
\text { CFU/mL, respectively) than } \\
\text { conventional heating; } \\
\text { Salmonella- N.D. }\end{array}$ & $\begin{array}{l}\text { Kumar and Hausain } \\
\text { (2014) }\end{array}$ \\
\hline Orange juice & $\begin{array}{l}\text { Bacteria, yeasts and } \\
\text { molds }\end{array}$ & $\begin{array}{c}\text { Frequency- } 50 \mathrm{~Hz} \\
\text { Temperature- } 90,120 \text {, and } 150{ }^{\circ} \mathrm{C} \\
\text { Time- } 1.13,0.85 \text {, and } 0.68 \mathrm{~s}\end{array}$ & $\begin{array}{c}\text { Complete inactivation of bacteria, } \\
\text { yeasts and molds; } \\
\text { Flavor remained intact; } \\
\text { Pectin esterase activity and Vitamin } \\
\text { C reduced by } 98 \text { and } 15 \%, \\
\text { respectively \& } \\
\text { Sensory qualities conserved. }\end{array}$ & $\begin{array}{l}\text { Leizerson and } \\
\text { Shimoni (2005) }\end{array}$ \\
\hline Orange juice & \multirow{2}{*}{$\begin{array}{c}\text { E.coli } \mathrm{O} 157: \mathrm{H} 7 \\
\text { Salmonella } \\
\text { typhimurium, Listeria } \\
\text { monocytogenes }\end{array}$} & $\begin{array}{c}\text { Electric field- } 10-20 \mathrm{~V} / \mathrm{cm} \\
\text { Frequency- } 60 \mathrm{~Hz} \\
\text { Time }-120-540 \mathrm{~s}\end{array}$ & \multirow{2}{*}{$\begin{array}{c}\text { E. coli } \mathrm{O} 157: \mathrm{H} 7 \text { reduced by }>5 \mathrm{log} \\
\text { CFU/ml after three treatments; } \\
\text { Similar results for Salmonella } \\
\text { typhimurium, Listeria } \\
\text { monocytogenes }\end{array}$} & \multirow[t]{2}{*}{ Sagong et al., (2011) } \\
\hline Tomato juice & & $\begin{array}{c}\text { Electric field- } 10-20 \mathrm{~V} / \mathrm{cm} \\
\text { Frequency- } 60 \mathrm{~Hz} \\
\text { Time }-90-480 \mathrm{~s}\end{array}$ & & \\
\hline Apple juice & E.coli $\mathrm{O} 157: \mathrm{H} 7$, & Electric field- $30,60 \mathrm{~V} / \mathrm{cm}$ & 5-log reduction of all three & Park et al., (2017) \\
\hline
\end{tabular}




\begin{tabular}{|c|c|c|c|c|}
\hline & $\begin{array}{c}\text { Salmonella } \\
\text { Typhimurium, Listeria } \\
\text { monocytogenes }\end{array}$ & $\begin{array}{c}\text { TSS- } 36,48{ }^{\circ} \text { Brix } \\
\text { Time- } 20,60 \mathrm{~s}\end{array}$ & pathogens. & \\
\hline Gochujang & Bacillus vegetative cells & $\begin{array}{l}\text { Electric field- } 30 \mathrm{~V} / \mathrm{cm} \\
\text { Frequency- } 60 \mathrm{~Hz} \\
\text { Temperature- } 100^{\circ} \mathrm{C} \\
\text { Time- } 150 \mathrm{~s}\end{array}$ & $\begin{array}{l}\text { Bacillus cells were reduced by } \\
99.7 \% \text { after ohmic heating. } \\
\text { Taste, flavor, color and texture of } \\
\text { OH samples were similar to those } \\
\text { of conventionally treated samples. }\end{array}$ & Cho et al., (2016) \\
\hline $\begin{array}{c}\text { Beef } \\
\text { meatballs }\end{array}$ & $\begin{array}{l}\text { Total mesophilic } \\
\text { aerobic bacteria, molds, } \\
\text { yeasts, } \\
\text { Staphylococcus aureus, } \\
\text { Salmonella } \text { spp., } \\
\text { Listeria monocytogenes }\end{array}$ & $\begin{array}{c}\text { Electric field- } 15.26 \mathrm{~V} / \mathrm{cm} \\
\text { Frequency- } 50 \mathrm{~Hz} \\
\text { Temperature- } 75{ }^{\circ} \mathrm{C} \\
\text { Holding time- } 0 \mathrm{~s}\end{array}$ & $\begin{array}{l}\text { Total mesophilic aerobic bacteria - } \\
2.47 \text { log reduction, } \\
\text { Molds and yeasts- N.D., } \\
\text { Staphylococcus aureus - N.D., } \\
\text { Salmonella } \text { spp., Listeria } \\
\text { monocytogenes cells not inactivated } \\
\text { efficiently. }\end{array}$ & Sengun et al., (2014) \\
\hline Meat & L. innocua & $\begin{array}{c}\text { LTLT: } \\
\text { Electric field: } 8.33 \mathrm{~V} / \mathrm{cm} \\
\text { Frequency- } 50 \mathrm{~Hz} \\
\text { Temperature- } 95^{\circ} \mathrm{C} \\
\text { Time- } 7 \mathrm{~min} \\
\text { HTST: } \\
\text { Electric field: } 8.33 \mathrm{~V} / \mathrm{cm} \\
\text { Frequency- } 50 \mathrm{~Hz} \\
\text { Temperature- } 72^{\circ} \mathrm{C} \\
\text { Time- } 15 \mathrm{~min}\end{array}$ & $\begin{array}{l}\text { Bacteria reduced to N.D. } \\
\text { LTLT samples has less cook loss } \\
\text { (29.3\%) than conventional method; } \\
\text { HTST sample had better color }\end{array}$ & Zell et al., (2010) \\
\hline Apple juice & $\begin{array}{c}\text { Alicyclobacillus } \\
\text { acidoterrestris }\end{array}$ & $\begin{array}{c}\text { Electric field }=26.7 \mathrm{~V} / \mathrm{cm} \\
\text { Frequency- } 25 \mathrm{kHz} \\
\text { Temperature- } 100{ }^{\circ} \mathrm{C} \\
\text { Time- } 30 \mathrm{~s}\end{array}$ & $\begin{array}{l}\text { Total inactivation of cells. } \\
\text { No significant change in TSS and } \\
\text { color }\end{array}$ & Kim et al., (2017) \\
\hline $\begin{array}{l}\text { Cloudberry } \\
\text { jam }\end{array}$ & Bacillus licheniformis & $\begin{array}{l}\text { Voltage varied to simulate thermal } \\
\text { conditions. }\end{array}$ & $\begin{array}{l}\text { D-value for OH sample less than } \\
\text { conventional heating. }\end{array}$ & Pereira et al., (2007) \\
\hline
\end{tabular}


Leizerson et al., (2005) used the electro heating unit for citrus juice comprised of two sets of contiguous graphite anodes, with a 20 $\mathrm{cm}$ hole between each match of anodes. The framework used an exchanging current at a recurrence of $50 \mathrm{~Hz}$ and at greatest voltage of $8 \mathrm{kV}$. The current and voltage were measured automatically by control system and thermocouple was inserted at the exit end of the heating chamber to detect the predetermined heating temperature.

\section{Physico-chemical changes of fruit juices exposed to ohmic heating}

\section{Effect on inactivation of enzymes}

There have been limited research works on enzyme inactivation of fruit juices. Castro et al., (2004) found that ohmic heating caused the faster deactivation of lipoxygenase and polyphenoloxidase than the common heating methods. Leizerson et al., (2005) concluded that the activity of pectin methyl esterase was reduced by $98 \%$ in orange juice exposed to ohmic heating. The deactivation of pepsin activity in grape juice was greatly influenced by $\mathrm{pH}$, electrical field strength, electrical conductivity (Yang et al., 2004). Margot et al., (1997) observed the inactivation of trypsin activity for the ohmic treated fruit juice within 55 to $70^{\circ} \mathrm{C}$ range of temperatures. Jakob et al., (2010) studied the mechanism of deactivation of pectin methylesterase in fresh apple juice during ohmic heating and concluded that kinetic parameters were significantly changed as compared to the conventional heating method. Wilinska et al., (2008) revealed that the deactivation of pectin methyl esterase in apple juice followed firstorder kinetics by exposing to ohmic treatment. Moreno et al., (2013) postulated that polyphenoloxidase was completely inactivated by ohmic heating assisted with vacuum impregnation at a temperature of 50 ${ }^{0} \mathrm{C}$ for which shelf life of apple juice was enhanced to more than 4 weeks. The microbiological study of ohmic heated food materials has been illustrated in table 1 .

\section{Changes in the heat sensitive compounds}

Sarkis et al., (2013) studied the degradation of anthocyanin compound in blueberry pulp by comparing in both ohmic and common heating methods. Degradation was found to be higher in ohmic heating at higher electric field. Assiry et al., (2003) observed the impact of ohmic heating which was found to be more effective in vitamin $\mathrm{C}$ degradation as compared to common heating methods. Mercali et al., (2012) observed that ascorbic acid in acerola pulp was degraded in the similar trend by exposing to both ohmic and common heating methods. Vikram et al., (2005) found that the ascorbic acid in orange juice was degraded to approximately $35 \%$ after 3 minutes of ohmic heating at a temperature of $90^{\circ} \mathrm{C}$ with $42 \mathrm{~V} / \mathrm{cm}$ of applied electrical field strength. Castro et al., (2004) revealed that the deterioration of ascorbic acid was following the first order kinetics in both ohmic and conventional heating methods and was independent of presence of electric field.

\section{Changes in $\mathrm{pH}$ and viscosity}

Singh et al., (2008) observed the variations of viscosity and electrical conductivity of apple, pineapple, tomato, and orange juices exposed to ohmic treatment and showed that with increasing the temperature, viscosity was decreasing.

Darvishi et al., (2013) found that there was a significant effect of voltage change on the $\mathrm{pH}$ of pomegranate juice samples and showed a nonlinear relationship during the treatment period.

\section{Changes in color}

Mercali et al., (2014) observed the higher change in the color parameters $\mathrm{L}^{*}, \mathrm{a}^{*}, \mathrm{~b}^{*}$ at 
low electric field frequency of $10 \mathrm{~Hz}$ which was due to electrochemical reactions. Icier et al., (2006) showed that the variation in colors followed the first order kinetics in pea puree during ohmic blanching with the electrical field strength of $20 \mathrm{~V} / \mathrm{cm}$.

In conclusion, development of new products and process technologies is necessary from the point of increasing demand of consumers for high quality foods. In ohmic heating, the conversion of electrical energy absorbed by the material into volumetric heating takes place without any surfacial heat loss. Uniform distribution of temperature as well as uniform heating is the main advantages of ohmic heating. Enzymatic browning causes color and quality degradation in fruit juices. So ohmic heating can be applicable as an alternative to convential heating to enhance the shelf life of fruit juices with minimal degradation of nutritional and organoleptic qualities.

\section{References}

Assiry, A., Sastry, S. K., Samaranayake, C. 2003. Degradation kinetics of ascorbic acid during ohmic heating with stainless steel electrodes. Journal of Applied Electrochemistry. 33(2): 187-196.

Castro, I., Macedo, B., Teixeira, J. A., Vicente, A. A. 2004. The effect of electric field on important food- processing enzymes: Comparison of inactivation kinetics under conventional and ohmic heating. Journal of Food Science. 69(9): C696C701.

Castro, I., Teixeira, J. A., Salengke, S., Sastry, S. K., Vicente, A. A. 2003. The influence of field strength, sugar and solid content on electrical conductivity of strawberry products. Journal of Food Process Engineering. 26(1): 17-29.

Castro, I., Teixeira, J. A., Salengke, S.,
Sastry, S. K., Vicente, A. A. 2004 Ohmic heating of strawberry products: electrical conductivity measurements and ascorbic acid degradation kinetics. Innovative Food Science and Emerging Technologies. 5(1): 27-36.

Cho, W. I., Yi, J. Y., Chung, M. S. 2016. Pasteurization of fermented red pepper paste by ohmic heating. Innovative Food Science and Emerging Technologies. 34: 180-186.

Darvishi, H., Hosainpour, A., Nargesi, F., Khoshtaghaza, M. H., Torang, H. 2011. Ohmic processing: temperature dependent electrical conductivities of lemon juice. Modern Applied Science. 5(1): 209.

Darvishi, H., Khostaghaza, M. H., Najafi, G. 2013. Ohmic heating of pomegranate juice: Electrical conductivity and $\mathrm{pH}$ change. Journal of the Saudi Society of Agricultural Sciences. 12(2): 101-108.

De Alwis, A., Halden, K., Fryer, P. J. 1989. Shape and conductivity effects in the ohmic heating of foods. Chemical Engineering Research and Design. 67(2): 159-168.

Icier, F., Ilicali, C. 2004. Electrical conductivity of apple and sourcherry juice concentrates during ohmic heating. Journal of Food Process Engineering. 27(3): 159-180.

Icier, F., Ilicali, C. 2005. Temperature dependent electrical conductivities of fruit purees during ohmic heating. Food Research International. 38(10): 11351142.

Icier, F., Ilicali, C. 2005. The effects of concentration on electrical conductivity of orange juice concentrates during ohmic heating. European Food Research and Technology. 220(3-4): 406-414.

Icier, F., Yildiz, H., Baysal, T. 2006. Peroxidase inactivation and colour changes during ohmic blanching of pea 
puree. Journal of Food Engineering. 74(3): 424-429.

Jakób, A., Bryjak, J., Wójtowicz, H., Illeová, V., Annus, J., Polakovič, M. 2010. Inactivation kinetics of food enzymes during ohmic heating. Food Chemistry. 123(2): 369-376.

Kaur, R., Gul, K., Singh, A. K. 2016. Nutritional impact of ohmic heating on fruits and vegetables- A review. Cogent Food and Agriculture, 2(1): 1159000.

Kim, H. J., Choi, Y. M., Yang, T. C., Taub, I. A., Tempest, P., Skudder, P. et al., Parrott, D. L. 1996. Validation of ohmic heating for quality enhancement of food products. Food technology (USA).

Kumar, M., Hausain, A. 2014. Effect of ohmic heating of buffalo milk on microbial quality and tesure of paneer. Asian Journal of Dairying and Foods Research. 33(1): 9-13.

Leizerson, S., Shimoni, E. 2005. Effect of ultrahigh-temperature continuous ohmic heating treatment on fresh orange juice. Journal of Agricultural and Food Chemistry. 53(9): 3519-3524.

Leizerson, S., Shimoni, E. 2005. Effect of ultrahigh-temperature continuous ohmic heating treatment on fresh orange juice. Journal of Agricultural and Food Chemistry. 53(9): 3519-3524.

Lima, M. 1996. Ascorbic acid degradation kinetics and mass transfer effects in biological tissue during ohmic heating (Doctoral dissertation, The Ohio State University).

Lima, M., Heskitt, B. F., Burianek, L. L., Nokes, S. E., Sastry, S. K. 1999. Ascorbic acid degradation kinetics during conventional and ohmic hieating. Journal of Food Processing and Preservation. 23(5): 421-443.

Marcotte, M., Ramaswamy, H. S., Piette, J. P. G. 1998. Ohmic heating behavior of hydrocolloid solutions. Food research International. 31(6-7): 493-502.
Margot, A., Flaschel, E., Renken, A. 1997. Empirical kinetic models for tryptic whey-protein hydrolysis. Process Biochemistry. 32(LGRC-ARTICLE1997-011): 217-223.

Mercali, G. D., Jaeschke, D. P., Tessaro, I. C., Marczak, L. D. F. 2012. Study of vitamin $C$ degradation in acerola pulp during ohmic and conventional heat treatment. LWT-Food Science and Technology. 47(1): 91-95.

Mercali, G. D., Schwartz, S., Marczak, L. D. F., Tessaro, I. C., Sastry, S. 2014. Ascorbic acid degradation and color changes in acerola pulp during ohmic heating: Effect of electric field frequency. Journal of Food Engineering. 123: 1-7.

Moreno, J., Simpson, R., Pizarro, N., Pavez, C., Dorvil, F., Petzold, G., Bugueño, G. 2013. Influence of ohmic heating/osmotic dehydration treatments on polyphenoloxidase inactivation, physical properties and microbial stability of apples (cv. Granny Smith). Innovative Food Science and Emerging Technologies. 20: 198-207.

Park, I. K., Ha, J. W., Kang, D. H. 2017. Investigation of optimum ohmic heating conditions for inactivation of Escherichia coli O157: H7, Salmonella enterica serovar Typhimurium, and Listeria monocytogenes in apple juice. BMC microbiology. 17(1): 117.

Pereira, R., Martins, J., Mateus, C., Teixeira, J. A., Vicente, A. A. 2007. Death kinetics of Escherichia coli in goat milk and Bacillus licheniformis in cloudberry jam treated by ohmic heating. Chemical Papers. 61(2): 121-126.

Qihua, T., Jindal, V. K., Van Winden, J. 1993. Design and performance evaluation of an ohmic heating unit for liquid foods. Computers and Electronics in Agriculture. 9(3): 243-253.

Sagong, H. G., Park, S. H., Choi, Y. J., Ryu, 
S., Kang, D. H. 2011. Inactivation of Escherichia coli O157: H7, Salmonella Typhimurium, and Listeria monocytogenes in orange and tomato juice using ohmic heating. Journal of food protection, 74(6), 899-904.

Sarang, S., Sastry, S. K., Knipe, L. 2008. Electrical conductivity of fruits and meats during ohmic heating. Journal of Food Engineering. 87(3), 351-356.

Sarkis, J. R., Mercali, G. D., Tessaro, I. C., Marczak, L. D. F. 2013. Evaluation of key parameters during construction and operation of an ohmic heating apparatus. Innovative food science and emerging technologies. 18: 145-154.

Sastry, S. K., Palaniappan, S. 1992. Mathematical modeling and experimental studies on ohmic heating of liquid particle mixtures in a static heater. Journal of Food Process Engineering, 15(4): 241-261.

Singh, S. P., Tarsikka, P. S., Singh, H. 2008. Study on viscosity and electrical conductivity of fruit juices. Journal of Food Science and Technology-Mysore, 45(4): 371-372.

Sun, H., Kawamura, S., Himoto, J. I., Itoh, K., Wada, T., Kimura, T. 2008. Effects of ohmic heating on microbial counts and denaturation of proteins in milk. Food science and technology research. 14(2): $117-123$.

Vikram, V. B., Ramesh, M. N., Prapulla, S. G. 2005. Thermal degradation kinetics of nutrients in orange juice heated by electromagnetic and conventional methods. Journal of Food Engineering. 69(1): 31-40.

Wilińska, A., de Figueiredo Rodrigues, A. S., Bryjak, J., Polakovič, M. 2008. Thermal inactivation of exogenous pectin methylesterase in apple and cloudberry juices. Journal of Food Engineering. 85(3): 459-465.

Yang, R., Li, S. Q., Zhang, Q. H. 2004. Effects of pulsed electric fields on the activity and structure of pepsin. Journal of Agricultural and Food Chemistry. 52:7400-7406. http://dx.doi.org/10.1021/jf049183p

Zareifard, M. R., Ramaswamy, H. S., Trigui, M., Marcotte, M. 2003. Ohmic heating behaviour and electrical conductivity of two-phase food systems. Innovative Food Science and Emerging Technologies. 4(1): 45-55.

\section{How to cite this article:}

Sourav Misra and Sitesh Kumar. 2020. Ohmic Heating as an Alternative to Conventional Heating for Shelf Life Enhancement of Fruit Juices. Int.J.Curr.Microbiol.App.Sci. 9(03): 0109. doi: https://doi.org/10.20546/ijcmas.2020.903.001 